\title{
Kajian Sifat Fisikokimia Tepung Jagung Pragelatinisasi Serta Aplikasinya Pada Pembuatan Bubur Instan
}

\section{Physicochemical Properties of Pregelatinized Corn Flour and Its Application on Instant Porridge Production}

Herlina Marta dan Tensiska ${ }^{1)}$

Staf Pengajar Departemen Teknologi Industri Pangan, FTIP-Unpad

Email Koresponden: herlina.marta@unpad.ac.id

\begin{tabular}{l} 
A R T I C L E IN F O \\
\hline Article history \\
Received: 24 Juni 2016 \\
Accepted: 17 Juli 2016 \\
Available online: Februari 2017 \\
\hline Keywords: \\
Cooking time \\
Pregelatinized \\
Corn flour \\
Physicochemical properties \\
Instant porridge \\
\hline Kata kunci:
\end{tabular}

Kata kunci :

Tepung jagung

Lama pemasakan

Pragelatinisasi

Sifat fisikokimia

Bubur instan

\begin{abstract}
A B STR A C T
This study was carried out to evaluate changes in physicochemical properties of corn flour treated by precooking of corn slurryand to apply the pragelatinized corn flour for instant porridge production. The research used an experimental method with Completely Randomized Design with five treatments cooking time of corn slurry $(0,5$, $10,15$, and $20 \mathrm{~min})$. The result showed the cooking time significantly $(p \leq 0,05)$ affectedgel strenght, bulk density, swelling volume, solubility, water absorption capacity, wettability, water content, crude protein content, and crude carbohydrate contentof pregelatinized corn flour but not significantly $(p \leq 0,05)$ affected ash content and lipid content. Swelling volume, solubility, water absorption capacity and water content were increased with increasing cooking timebutgel strength, bulk density, wettability, crude protein content and crude carbohydrate content were decreased.The Formulation B (corn flour $40 \mathrm{~g}$, skim milk $45 \mathrm{~g}$, fine sugar $5 \mathrm{~g}$, and vegetable oil $10 \mathrm{~g}$ ) ofcorn instant porridge had macro nutritions complied with the standard (SNI). It had good swelling power, solubility, water absorption capacity and wettability.The corn instant porridge had protein digestibility of $87,54-88,67 \%$ $(\mathrm{db})$ and starch digestibility of $82,39-83,87 \%(\mathrm{db})$. Sensory acceptabilitiesof the corn instant porridge were not significantly different $(p \leq 0,05)$ from commercial instant porridge forsupplementary infant food, except color and aroma.
\end{abstract}

\section{A B S T R A K}

Penelitian ini bermaksud untuk mempelajari perubahan sifat fisikokimia tepung jagung yang diberi perlakuan lama pemasakan slurry jagung dan bertujuan untuk mengaplikasikan tepung jagung pragelatinisasi tersebut dalam pembuatan bubur instan. Penelitian menggunakan Rancakan Acak Lengkap faktor tunggal dengan lima perlakuan yang terdiri dari lama pemasakan slurry jagung 0, 5, 10, 15 dan 20 menit. Hasil penelitian menunjukkan bahwa perlakuan lama pemasakan memberikan pengaruh yang signifikan $(\mathrm{p} \leq 0,05)$ terhadap kekuatan gel, densitas kamba, swelling volume, solubility, kapasitas penyerapan air, wettability, kadar air, kadar protein kasar, dan kadar karbohidrat tepung jagung pragelatinisasi, namun tidak berpengaruh secara signifikan terhadap kadar abu dan kadar lemaknya. Swelling volume, solubility, kapasitas penyerapan air dan kadar air cenderung meningkat dengan semakin lamanya pemasakan. Sebaliknya, kekuatan gel, densitas kamba, wettability, kadar protein kasar dan kadar karbohidrat cenderung menurun. Bubur jagung instan dengan formulasi sebagai berikut: Tepung jagung 40 gram, susu skim 45 gram, gula halus 5 gram dan minyak nabati 10 gram memiliki kandungan zat gizi makro yang sudah sesuai dengan SNI. Kedua formulasi bubur jagung instan memiliki sifat fisik yang baik, daya cerna protein $87,54-88,67 \%$ bk dan daya cerna pati $82,89-83,87 \%$ bk. Sifat organoleptik untuk kedua formulasi bubur jagung instan tidak berbeda secara signifikan dengan sifat organoleptik bubur instan komersial, kecuali kesukaan terhadap warna dan aroma. 


\section{Pendahuluan}

Jagung (Zea mays) merupakan salah satu serealia yang strategis dan bernilai ekonomis serta mempunyai peluang untuk dikembangkan karena kedudukannya sebagai sumber utama karbohidrat dan protein setelah beras. Berdasarkan komposisi kimia dan kandungan zat gizinya, jagung mempunyai prospek sebagai bahan pangan dan bahan baku industri.

Kebutuhan jagung terus meningkat seiring dengan meningkatnya bahan baku untuk pangan maupun pakan. Di Indonesia, produksi jagung sebagai bahan pangan pokok berada di urutan ketiga setelah padi dan ubi kayu. Produksi jagung nasional selama lima tahun terakhir cenderung meningkat yaitu sebesar 12.523 .894 ton pada tahun 2005 hingga 17.041.251 ton pada tahun 2009 dengan rata-rata kenaikan 7,21 persen per tahun (BPS, 2010). Alternatif produk yang dapat dikembangkan dari jagung mencakup produk olahan segar, produk primer (beras jagung, tepung, dan pati), produk siap santap (marning, emping), dan produk instan (beras jagung instan, pati jagung untuk gula, sirup glukosa, sirup fruktosa, maltosa, sorbitol, bioetanol), sedangkan limbah jagung dapat digunakan sebagai pakan ternak (Richana \& Suarni, 2007).

Untuk memenuhi kebutuhan jagung untuk dikonsumsi langsung, masyarakat di beberapa daerah membuat tepung jagung dengan peralatan sederhana dengan menggunakan metode perendaman dan tanpa perendaman. Tepung jagung dipilih sebagai langkah awal diversifikasi jagung karena memiliki beberapa keunggulan antara lain: (i) tepung jagung lebih luas penggunaannya sebagai bahan baku dalam pembuatan berbagai macam produk olahan pangan; (ii) penyimpanan tepung lebih mudah dan umur simpan lebih lama; (iii) adanya defisiensi beberapa zat gizi dapat lebih mudah difortifikasi atau disuplementasi jika dalam bentuk tepung; dan (iv) lebih mudah bercampur dengan bahan lain (komposit).

Informasi mengenai sifat fisikokimia tepung sangat bermanfaat dalam aplikasi untuk mendisain beberapa produk pangan yang cocok dibuat berdasarkan sifat-sifat tersebut. Beberapa penelitian mengenai sifat fisikokimia berbagai jenis tepung sudah banyak dilakukan di antaranya tepung beras (Kadan et al., 2003), tepung gandum (Graybosch et al., 2003), tepung ubi jalar (Chun \& Yoo, 2006) dan tepung sorgum (Elkhalifa et al., 2005). Namun, informasi mengenai sifat fisikokimia tepung jagung yang mengalami proses pragelatinisasi menggunakan drum dryer masih terbatas.

Tepung pragelatinisasi atau tepung instan adalah tepung yang telah mengalami proses pemasakan atau gelatinisasi terlebih dahulu sebelum dikeringkan agar bersifat mudah terdispersi di dalam air dingin membentuk suspensi yang stabil. Menurut Linden \& Lorient (1995), penerapan tepung pregelatinisasi untuk produk instan sudah meluas di bidang industri makanan, diantaranya pada tahap preparasi berbagai produk instan seperti saus, flake, powder food, crackers, snack dan sebagainya. Sifat fungsional yang harus dimiliki oleh tepung pragelatinisasi adalah kelarutan yang tinggi, sifat dispersi yang baik dan kemudahan untuk dicerna.

Dalam penelitian ini, tepung jagung pragelatinisasi digunakan sebagai bahan dasar dalam pembuatan bubur instan. Aplikasi tepung pragelatinisasi sebagai bahan dasar pembuatan bubur instan bertujuan untuk memudahkan proses preparasi bubur tersebut. Berdasarkan hasil studi yang telah dilakukan oleh beberapa peneliti, tepung jagung yang dibuat melalui proses pragelatinisasi memiliki viskositas yang lebih rendah dibandingkan tepung jagung tanpa proses pragelatinisasi serta menghasilkan gel yang lebih lunak. Sifat tepung jagung nikstamal ini cocok digunakan sebagai bahan baku dalam pembuatan bubur instan, dimana pada pembuatan bubur instan tidak diinginkan viskositas yang terlalu tinggi agar bubur tersebut bebas gumpalan, mudah disuapkan dengan sendok dan mudah ditelan.

Penelitian ini bertujuan untuk mengetahui pengaruh proses lama pemasakan slurry jagung terhadap sifat fisikokimia tepung jagung yang dihasilkan dan perlakuan terbaik pada tahap I yaitu tepung jagung dengan lama pemasakan terbaik akan diaplikasikan sebagai bahan baku dalam pembuatan bubur instan dengan perlakuan formulasi yang berbeda. Untuk mengetahui formulasi bubur instan yang terbaik, maka dilakukan analisis karakteristik kimia, fisik, daya cerna dan sifat organoleptic terhadap sampel bubur instan tersebut.

\section{Metode Penelitian \\ Bahan dan Alat Penelitian}

Bahan utama dalam penelitian ini adalah jagung pipil varietas NK 33. Bahan untuk pembuatan bubur instan adalah susu skim, tepung gula dan minyak sawit. Bahan-bahan kimia untuk analisis proksimat dan analisis daya cerna protein dan daya cerna pati.

Alat yang digunakan dalam penelitian ini yaitu seperangkat alat untuk pembuatan tepung meliputi blender, drum dryer, disc mill, serta alat-alat untuk analisis meliputi texture analyzer, viscometer Brookfield, alat sentrifugasi, spektrofotometer, waterbath, $\mathrm{pH}$-meter dan peralatan untuk analisis proksimat.

\section{Rancangan Percobaan dan Analisis Data.}

Penelitian menggunakan Rancangan Acak Kelompok (RAK) faktor tunggal yang terdiri atas 5 perlakuan lama pemasakan slurry jagung $(0,5,10,15$ dan 20 menit). Analisis data dilakukan menggunakan metode oneway ANOVA pada program SPSS versi 17. Jika masing-masing perlakuan memberikan pengaruh yang berbeda nyata terhadap parameter yang diuji maka dilakukan uji lanjut Duncan pada program yang sama.

Tahapan Penelitian. Penelitian terdiri atas 2 tahap yaitu:

1. Pembuatan tepung jagung pragelatinisasi dengan berbagai kombinasi lamapemasakanslurry jagung (Gambar 1). Tepung jagung pragelatinisasi dianalisis sifat fisik dan sifat kimianya. Analisis sifat fisik 
meliputi: kekuatan gel, densitas kamba,swelling volume, solubility, kapasitas penyerapan air, dan wettability, sedangkan sifat kimia yang diamati meliputi kadar air, kadar protein, kadar lemak, kadar karbohidrat dan kadar abu.

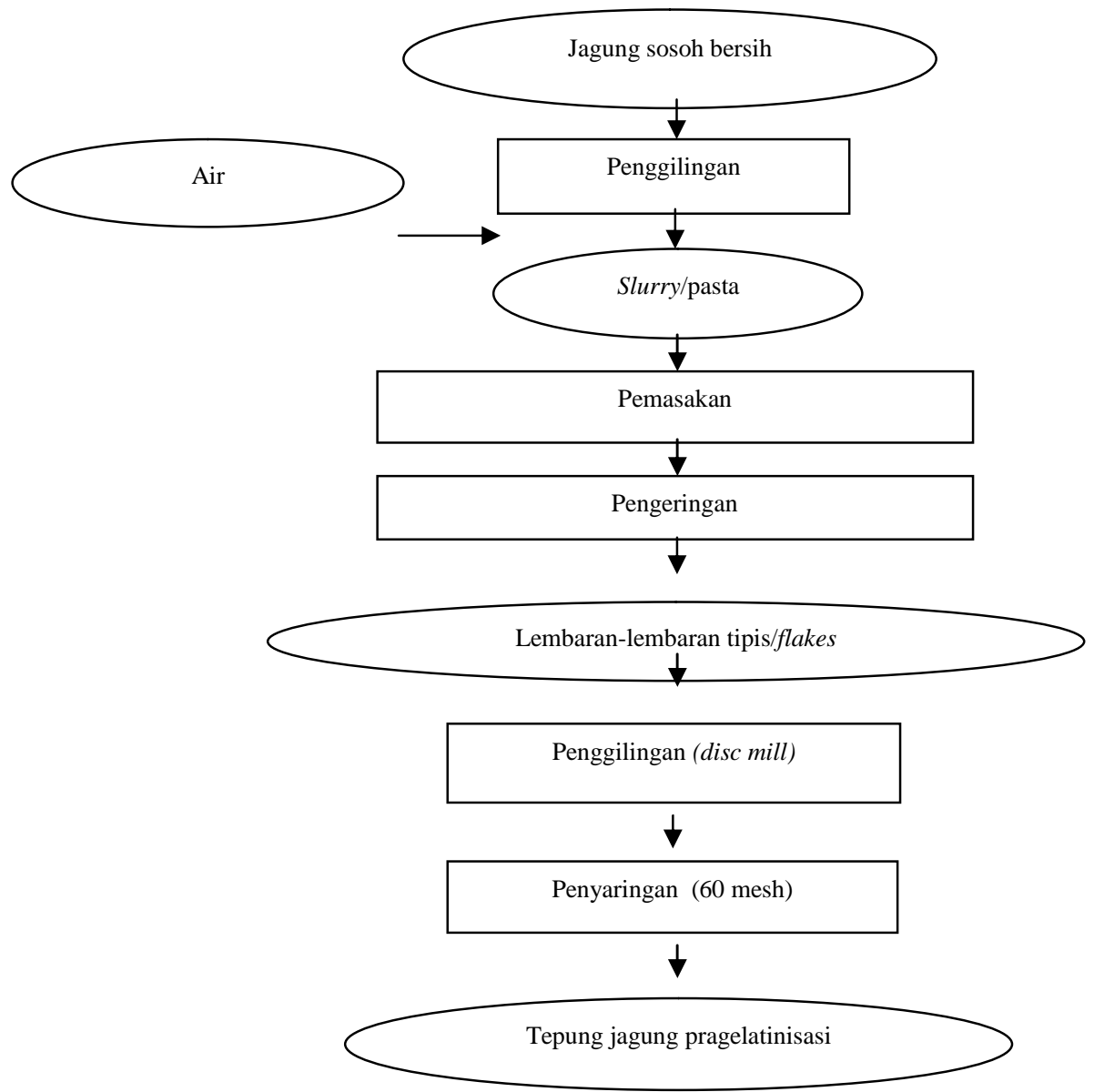

Gambar 1. Proses Pembuatan Tepung Jagung Pragelatinisasi

2. Aplikasi penggunaan tepung jagung pragelatinisasi dalam pembuatan bubur instan Tepung jagung pragelatinisasi yang dihasilkan pada tahap I digunakan sebagai bahan baku dalam pembuatan bubur instan. Formulasi bubur jagung instan yang dibuat pada penelitian ini adalah formulasi dasar bubur instan MP-ASI dengan menggunakan bahanbahan yang merupakan sumber zat gizi makro (karbohidrat, protein dan lemak) tanpa penambahan zat gizi mikro (vitamin dan mineral). Pada penelitian dibuat dua macam formulasi bubur jagung instan. Kedua formulasi ini berbeda dalam hal jumlah masing-masing bahan penyusunnya (Tabel 1). Oleh karena pada pembuatan bubur instan ini tidak ditambahkan zat gizi mikro, maka pemilihan formulasi bubur instan mengacu kepada persyaratan zat gizi makro MP-ASI bubuk instan pada SNI 01-7111.1-2005. Pembuatan bubur jagung instan menggunakan metode pencampuran kering yaitu dengan mencampurkan semua bahan sedikit demi sedikit sesuai dengan formulasi, kemudian dilakukan pengadukan secara manual untuk menghomogenan campuran tersebut.

Tabel 1. Formulasi Bubur Jagung Instan

\begin{tabular}{ccc}
\hline Bahan-Bahan & Formulasi A & Formulasi B \\
\hline Tepung jagung $(\mathrm{g})$ & 45 & 40 \\
Susu skim $(\mathrm{g})$ & 40 & 45 \\
Gula halus $(\mathrm{g})$ & 10 & 5 \\
Minyak nabati $(\mathrm{g})$ & 5 & 10 \\
\hline
\end{tabular}

Bubur jagung instan yang dihasilkan selanjutnya dianalisis sifat kimia (kadar proksimat, kadar kalsium dan $\mathrm{pH}$ ), sifat fisik (densitas kamba, uji seduh, waktu rehidrasi dan kapasitas penyerapan air), daya cerna (protein dan pati), serta sifat organoleptiknya menggunakan uji hedonik (warna, aroma, rasa, kekentalan dan penerimaan umum). 


\section{Hasil Pembahasan}

Sifat Fisik Tepung Jagung Instan. Perlakuan lama pemasakan slurry jagung menyebabkanadanya pengaruh yang signifikan terhadap kekuatan gel, densitas kamba, swelling volume, solubility, kapasitas penyerapan air dan wettability tepung tepung jagung pragelatinisasi (Tabel 2). Kekuatan gel tepung jagung pragelatinisasicenderung menurun dengan semakin lamanya pemasakan slurry jagung.Selama pemasakan slurry jagung terjadi leachingpadatan ke dalam medium pemasakan. Semakin lama waktu pemasakan slurry jagung maka akan semakin banyak pula padatan yang mengalami leaching. Menurut Mondragon et al., (2006), stabilisasi jaringan gel berhubungan dengan pengembangan struktur kristalin lokal karena penggabungan kembali molekul amilosa. Semakin lama pemasakan slurry jagung, maka semakin banyak pula molekul amilosa yang mengalami leaching, sehingga jumlah molekul amilosa yang akan bergabung kembali pada saat pendinginan menjadi lebih sedikit. Hal inilah yang menyebabkan semakin rendahnya kekuatan gel tepung jagung pragelatinisasi dengan semakin lamanya pemasakan slurry jagung.

Tabel 2. Pengaruh Lama Pemasakan Slurry Jagung Terhadap Sifat Fungsional Tepung Jagung Pragelatinisasi

\begin{tabular}{ccccccc}
\hline Lama Pemasakan & $\begin{array}{c}\text { Kekuatan gel } \\
(\mathrm{gf})\end{array}$ & $\begin{array}{c}\text { Densitas } \\
\text { Kamba } \\
(\mathrm{g} / \mathrm{ml})\end{array}$ & $\begin{array}{c}\text { Swelling } \\
\text { Volume }(\mathrm{ml} / \mathrm{g} \\
\mathrm{bk})\end{array}$ & $\begin{array}{c}\text { Solubility } \\
(\% \mathrm{bk})\end{array}$ & $\begin{array}{c}\text { Kapasitas } \\
\text { Penerapan } \\
\text { Air } \\
(\mathrm{g} / \mathrm{g} \mathrm{bk})\end{array}$ & $\begin{array}{c}\text { Wettability } \\
\text { (detik) }\end{array}$ \\
\hline 0 menit & $129,15 \mathrm{e}$ & $0,210 \mathrm{~d}$ & $8,79 \mathrm{a}$ & $34,16 \mathrm{a}$ & $8,23 \mathrm{a}$ & $15,25 \mathrm{~b}$ \\
$10 \mathrm{menit}$ & $127,38 \mathrm{~d}$ & $0,206 \mathrm{~d}$ & $9,29 \mathrm{a}$ & $34,77 \mathrm{ab}$ & $8,48 \mathrm{ab}$ & $15,00 \mathrm{~b}$ \\
15 menit & $98,80 \mathrm{c}$ & $0,184 \mathrm{c}$ & $9,71 \mathrm{a}$ & $37,14 \mathrm{bc}$ & $8,59 \mathrm{ab}$ & $11,50 \mathrm{a}$ \\
20 menit & $91,90 \mathrm{~b}$ & $0,155 \mathrm{~b}$ & $10,86 \mathrm{~b}$ & $37,01 \mathrm{bc}$ & $8,68 \mathrm{c}$ & $10,50 \mathrm{a}$ \\
25 menit & $77,50 \mathrm{a}$ & $0,133 \mathrm{a}$ & $10,93 \mathrm{~b}$ & $38,59 \mathrm{c}$ & $8,67 \mathrm{c}$ & $10,00 \mathrm{a}$ \\
\hline
\end{tabular}

Keterangan: Angka yang diikuti dengan huruf sama pada satu kolom menunjukkan tidak beda nyata pada taraf $5 \%$.

Densitas kamba dan wettabilitytepung jagung pragelatinisasi cenderung semakin menurun dengan semakin lamanya pemasakanslurry jagung. Semakin lama pemasakan slurry jagung semakin tinggi tingkat gelatinisasi pati jagung. Menurunnya nilai densitas kamba dan wettability tepung jagung pragelatinisasi disebabkan oleh semakin tingginya tingkat gelatinisasi pati pada tepung jagung, dimana semakin tinggi tingkat gelatinisasi suatu bahan maka akan semakin tinggi pula porositas bahan tersebut.

Semakin lama pemasakan slurry jagung maka swelling volume dan solubility tepung jagung pragelatinisasi cenderung meningkat. Peningkatan swelling volume dan solubility ini berhubungan dengan meningkatnya jumlah amilosa dan amilopektin yang leaching dari granula pati. Lebih lanjut Tan \& Chinnaswamy (1993) menjelaskan bahwa peningkatan swelling volume dan solubility dapat disebabkan oleh tingkat disorganisasi makromolekuler dan jenis degradasi pati. Semakin lama pemasakan slurry jagung maka akan semakin tinggi tingkat disorganisasi molekuler pati sehingga semakin meningkat swelling volume dan solubility tepung jagung pragelatinisasi tersebut.

Swelling volumejuga berhubungan dengan kapasitas penyerapan air tepung jagung tersebut. Berdasarkan hasil penelitian Marta (2011), swelling volume tepung jagung berkorelasi dengan kapasitas penyerapan air tepung jagung tersebut dengan koefisien korelasi sebesar $\mathrm{r}=0,865 ; \mathrm{p} \leq 0,01$. Swelling volume dipengaruhi oleh kemampuan molekul pati untuk mengikat air melalui pembentukan ikatan hidrogen. Setelah gelatinisasi ikatan hidrogen antara molekul pati terputus dan digantikan oleh ikatan hidrogen dengan air. Pembengkakan granula pati secara cepat yang disebabkan oleh putusnya ikatan hidrogen intermolekuler pada area daerah amorf terjadi pada suhu di bawah $70{ }^{\circ} \mathrm{C}$ (De la Torre-Gutiérrez et al. 2008). Hal ini dapat menjelaskan bahwa semakin tinggi kapasitas penyerapan air, maka semakin tinggi pula swelling volume tepung jagung.

Kapasitas penyerapan air memberikan gambaran jumlah air yang tersedia untuk gelatinisasi. Kapasitas penyerapan air yang rendah diinginkan dalam pembuatan bubur (Elkhalifa et al., 2005). Menurut Hodge \& Osman (1976), tepung yang memiliki KPA tinggi memiliki gugus hidrofilik yang lebih banyak. Lebih lanjut Hoover \& Sosulski (1986) menjelaskan bahwa perbedaan KPA bahan dapat disebabkan oleh perbedaan tingkat pengikatan gugus hidroksil yang membentuk ikatan hidrogen dan ikatan kovalen antar rantai pati.Semakin lama pemasakan slurry jagung, semakin tinggi pula KPA tepung jagung pragelatinisasi. Pemasakan slurry jagung dapat meningkatkan gelatinisasi pati dan porositas tepung jagung yang dihasilkan. Pati yang tergelatinisasi memiliki gugus hidrofilik yang lebih banyak untuk berikatan dengan air dan porositas tepung juga dapat memfasilitasi penyerapan air(Ma et al., 2011).Pendapat ini didukung oleh BeMiller \& Whistler (1997) yang menyatakan bahwa pati yang mengalami gelatinisasi akan kehilangan kristalinitasnya dan meningkat kemampuannya untuk mengikat air, sehingga semakin lama pemasakan slurry jagung maka semakin tinggi pula tingkat gelatinisasi dan KPA tepung jagung pragelatinisasi tersebut.

Peningkatan KPA juga dapat disebabkan oleh denaturasi protein yang menghasilkan residu asam amino yang memiliki kemampuan berikatan dengan air (Catsimpoolas \& Meyer, 1970). Semakin lama pemasakan slurry jagung, maka semakin tinggi tingkat denaturasi protein yang terdapat dalam tepung jagung 
pragelatinisasi, sehingga makin meningkat pula KPA tepung tersebut. Pengembangan serat kasar selama pemasakan juga berkontribusi untuk meningkatkan KPA tepung (Aguilera et al., 2009). Tepung yang memiliki KPA yang tinggi, baik digunakan sebagai ingredien dalam pembuatan produk-produk bakery.

Sifat Kimia Tepung Jagung Pragelatinisasi. Hasil analisis ragam menunjukkan perlakuan lama pemasakan slurry jagung mamberikan pengaruh yang signifikan terhadap kadar air, kadar protein dan kadar karbohidrattepung jagung pragelatinisasi, namun tidak berpengaruh secara signifikan terhadap kadar abu dan kadar lemaknya ( $\mathrm{p} \leq 0,05)$. Semakin lama pemasakan slurry jagung, semakin meningkat pula kadar air tepung jagung pragelatinisasi, sebaliknya semakin menurun kadar protein dan kadar karbohidratnya (Tabel 3).

Tabel 3. Pengaruh Lama Pemasakan Slurry terhadap Sifat Kimia Tepung Jagung Pragelatinisasi

\begin{tabular}{cccccc}
\hline Lama Pemasakan & $\begin{array}{c}\text { Kadar air } \\
(\% \mathrm{bk})\end{array}$ & $\begin{array}{c}\text { Kadar abu } \\
(\% \mathrm{bk})\end{array}$ & $\begin{array}{c}\text { Kadar protein }(\% \\
\mathrm{bk})\end{array}$ & $\begin{array}{c}\text { Kadar } \\
\text { lemak } \\
(\% \mathrm{bk})\end{array}$ & $\begin{array}{c}\text { Kadar karbohidrat } \\
\text { bk })\end{array}$ \\
\hline 0 menit & $7,79 \mathrm{a}$ & $1,028 \mathrm{a}$ & $7,91 \mathrm{c}$ & $2,34 \mathrm{a}$ & $80,92 \mathrm{c}$ \\
10 menit & $8,23 \mathrm{~b}$ & $1,027 \mathrm{a}$ & $7,81 \mathrm{bc}$ & $2,31 \mathrm{a}$ & $80,62 \mathrm{~b}$ \\
15 menit & $8,41 \mathrm{bc}$ & $1,026 \mathrm{a}$ & $7,77 \mathrm{~b}$ & $2,33 \mathrm{a}$ & $80,46 \mathrm{ab}$ \\
20 menit & $8,59 \mathrm{c}$ & $1,027 \mathrm{a}$ & $7,63 \mathrm{a}$ & $2,29 \mathrm{a}$ & $80,46 \mathrm{ab}$ \\
25 menit & $8,90 \mathrm{~d}$ & $1,028 \mathrm{a}$ & $7,56 \mathrm{a}$ & $2,24 \mathrm{a}$ & $80,26 \mathrm{a}$ \\
\hline
\end{tabular}

Keterangan: Angka yang diikuti dengan huruf sama pada satu kolom menunjukkan tidak beda nyata pada taraf $5 \%$.

Semakin lama pemasakan slurry jagung semakin meningkat pula tingkat gelatinisasi pati yang terdapat dalam tepung jagung tersebut. Menurut Khomsatin (2011) tingkat gelatinisasi berkorelasi positif dengan kadar air tepung jagung dengan koefisien korelasi sangat tinggi $(\mathrm{r}=$ 0,99). Lebih lanjut Sefa-Dedeh et al., (2004) menjelaskan bahwa gelatinisasi pati jagung selama pemasakan menyebabkan pati tersebut dapat menyerap air dengan lebih mudah dan cepat.

Berdasarkan hasil analisis proksimat kadar air dan kadar abu sampel tepung jagung pragelatinisasi yang dihasilkan berkisar antara 7,79-8,90\% bk dan 1,026$1,028 \%$ bk.Standar Nasional Indonesia (SNI) mengenai tepung jagung pragelatinisasi belum ada sehingga sebagai bahan perbandingan pada penelitian ini digunakan SNI tepung jagung, dimana pada SNI 01-3727-1995, kadar air maksimum tepung jagung sebesar $10 \%$ bb dan kadar abu maksimum 1,5\% bb. Dengan demikian, kadar air dan kadar abu tepung jagung pragelatinisasi untuk semua perlakuan lama pemasakan tersebut sudah memenuhi SNI 01-3727-1995.

Semakin lama pemasakan slurry jagung, semakin menurun kadar protein dan kadar karbohidrat tepung jagung pragelatinisasi. Proses pemasakan melibatkan penggunaan panas, dimana proses pemanasan yang berlebihan dapat menyebabkan kerusakan/ denaturasi protein. Menurut Winarno (2004), denaturasi diartikan suatu proses terpecahnya ikatan hidrogen, interaksi hidrofobik, ikatan garam, dan terbukanya lipatan molekul protein. Ada dua macam denaturasi, yaitu pengembangan rantai peptida dan pemecahan protein menjadi unit yang lebih kecil tanpa disertai pengembangan molekul ikatan.
Lebih lanjut Yohana (2000) menjelaskan bahwa denaturasi protein dapat menyebabkan terbentuknya peptida sederhana, asam amino, senyawa amin dan amonia yang mudah menguap. Penurunan kadar karbohidrat tepung jagung pragelatinisasi dikarenakan perlakuan panas melalui proses pemasakan dapat menyebabkan degradasi/kerusakan karbohidrat.

Berdasarkan hasil sifat fungional dan kimia tepung jagung pragelatinisasi yang dihasilkan pada penelitian tahap 1, maka tepung jagung yang digunakan pada pembuatan bubur jagung instan ini adalah tepung jagung pragelatinisasi dengan perlakuanlama pemasakan slurry jagung 15 menit. Pemilihan tepung jagung pragelatinisasi dengan perlakuan lama pemasakan 15 menit dikarenakan tepung jagung tersebut memiliki sifat fisik yang sesuai dalam pembuatan bubur instanyaitu memiliki swelling volume, solubility tinggi, wettability cepat, kekuatan gel rendah, kapasitas penyerapan air cukup dan komposisi kimia yang masih baik.

Karakteristik Bubur Jagung Instan. Analisis proksimat yang dilakukan meliputi analisis kadar air, kadar abu, kadar lemak, kadar protein, dan kadar karbohidrat. Sebagai acuan kandungan zat gizi makro (karbohidrat, protein, lemak) digunakan SNI-01-7111.1-2005 yaitu SNI mengenai MP-ASI bubuk instan. Kandungan zat gizi makro (untuk 100 gram produk) MP-ASI bubuk instan berdasarkan SNI 01-7111.1-2005 adalah protein sebesar 8-22 gram, lemak sebesar 6-15 gram dan energi minimal 400 kilokalori. Komposisi kimia kedua sampel bubur jagung instan dapat dilihat pada Tabel 4. 
Tabel 4. Pengaruh Formulasi terhadap Karakteristik Kimia, Fisik, Daya Cerna dan Sifat Organoleptik Bubur Jagung Instan MP-ASI

\begin{tabular}{|c|c|c|c|c|}
\hline Parameter & Formulasi A & Formulasi B & $\begin{array}{c}\text { Bubur } \\
\text { Komersial }\end{array}$ & $\begin{array}{c}\text { Persyaratan SNI 01- } \\
7111.1-2005\end{array}$ \\
\hline \multicolumn{5}{|l|}{ Komposisi kimia } \\
\hline Air & 3,87 & 3,85 & & maks $4 \%$ \\
\hline Protein (\%bk) & 14,31 & 15,21 & $14,58^{*}$ & 8-22 \\
\hline Lemak (\%bk) & 4,53 & 6,66 & $6,25 *$ & $6-15$ \\
\hline Karbohidrat (\%bk) & 74,38 & 71,27 & $70,83^{*}$ & - \\
\hline $\mathrm{Abu}(\% \mathrm{bk})$ & 2,91 & 3,01 & - & maks 3,5 \\
\hline Energi (kkal) & 395,53 & 405,86 & 397,89 & 400 \\
\hline \multicolumn{5}{|l|}{ Sifat fisik } \\
\hline Densitas kamba (g/ml) & 0,38 & 0,45 & 0,52 & - \\
\hline Uji seduh $(\mathrm{ml})$ & 60 & 48 & 125 & - \\
\hline Waktu rehidrasi (detik) & 23 & 24 & 58 & - \\
\hline Kapasitas penyerapan air & 2,63 & 2,65 & 4,06 & - \\
\hline \multicolumn{5}{|l|}{ Daya Cerna } \\
\hline Daya cerna protein (\%bk) & 87,54 & 88,67 & $88,81^{* *}$ & - \\
\hline Daya cerna pati (\%bk) & 83,87 & 82,39 & $86,14^{* *}$ & - \\
\hline \multicolumn{5}{|l|}{ Sifat organoleptik } \\
\hline Warna & $5,71^{\mathrm{a}}$ & $5,74^{\mathrm{a}}$ & $4,44^{\mathrm{b}}$ & - \\
\hline Aroma & $5,11^{\mathrm{b}}$ & $5,08^{b}$ & $5,82^{\mathrm{a}}$ & - \\
\hline Kekentalan & $5,45^{\mathrm{a}}$ & $5,33^{\mathrm{a}}$ & $4,98^{a}$ & - \\
\hline Rasa & $4,77^{\mathrm{a}}$ & $4,66^{\mathrm{a}}$ & $4,82^{\mathrm{a}}$ & - \\
\hline Overall & $5,21^{\mathrm{a}}$ & $5,18^{\mathrm{a}}$ & $5,15^{\mathrm{a}}$ & - \\
\hline
\end{tabular}

Keterangan: Angka yang diikuti dengan huruf sama pada satu barismenunjukkan tidak beda nyata padataraf $5 \%$

* Pembacaaan di label kemasan

**Hasil penelitian Mirdhayati (2004)

Kadar protein pada sampel bubur jagung instan Formulasi B lebih tinggi dibandingkan kadar protein bubur MP-ASI komersial. Perbedaan kadar protein antara kedua sampel bubur jagung instan dengan kadar protein bubur MP-ASI komersial dapat disebabkan oleh perbedaan bahan baku dan proses pengolahannya, dimana pada pembuatan bubur jagung instan dilakukan pencampuran secara kering. Metode pencampuran kering dapat meminimalkan kerusakan zat gizi bubur instan termasuk kadar proteinnya. Persyaratan SNI 017111.1.2005 mengenai kadar protein MP-ASI bubuk instan antara 8-22\%. Oleh karena itu kadar protein pada kedua sampel bubur jagung instan ini telah sesuai dengan standar.

Kadar lemak sampel bubur jagung instanFormulasi A sebesar4,53\% (bk) dan kadar lemak bubur jagung instan Formulasi B sebesar 6,66\% (bk). Kandungan lemak bubur jagung instan Formulasi A lebih rendah dari kandungan lemak bubur jagung instan Formulasi B. Hal ini disebabkan pada Formulasi B minyak nabati yang digunakan dua kali lipat lebih banyak daripada Formulasi A. Kadar lemak bubur jagung instan Formulasi A tidak memenuhi persyaratan kadar lemak MP-ASI bubuk instan yang dipersyaratkan oleh SNI 01-7111.1.2005.

Kadar abu untuk kedua sampel bubur jagung instan sebesar 2,91\% bk untuk Formulasi A dan 3,01\% bk untuk Formulasi B. Kadar abu untuk kedua sampel bubur jagung instan ini sudah sesuai dengan persyaratan SNI 017111.1.2005 yaitu maksimal 3,5\%.
Densitas kamba yang kecil berarti bahan tersebut membutuhkan volume yang besar untuk sejumlah kecil bahan. Bahan pangan yang kamba akan membutuhkan tempat yang lebih luas dibandingkan dengan bahan yang densitas kambanya besar untuk berat bahan yang sama.

Nilai densitas kamba produk bubur jagung instan dapat dilihat pada Tabel 4. Nilai densitas kamba untuk bubur jagung instan Formulasi A lebih kecil dibandingkan bubur jagung instan Formulasi B. Hal ini disebabkan bubur jagung instan Formulasi A menggunakan tepung jagung instan yang lebih banyak jumlahnya dibandingkan susu skim, dimana densitas kamba tepung jagung instan lebih kecil dari susu skim sehingga berpengaruh pada densitas kamba bubur jagung instan. Jika dibandingkan dengan nilai densitas kamba bubur MP-ASI komersial, kedua sampel bubur jagung MP-ASI ini memiliki nilai densitas kamba yang lebih kecil, yang menandakan bubur jagung instan ini lebih kamba.

Uji seduh merupakan gambaran dari rasio rehidrasi antara jumlah air yang ditambahkan dengan jumlah bahan makanan setiap penyajian. Jumlah air yang ditambahkan pada kedua sampel bubur jagung instan lebih sedikit dibandingkan jumlah air yang ditambahkan pada bubur MP-ASI komersial. Penambahan air untuk merehidrasi bubur jagung instan Formulasi B lebih sedikit dibandingkan bubur jagung instan Formulasi A, sehingga pada kekentalan yang sama volume menjadi lebih kecil. Volume kecil ini sangat baik bagi makanan bayi karena bayi menjadi tidak cepat kenyang dan asupan gizinya terpenuhi. Jumlah air yang ditambahkan untuk 
membentuk bubur MP-ASI tidak boleh terlalu banyak karena dapat menyebabkan perut bayi menjadi kembung dan kenyang sebelum kebutuhan energinya tercukupi.

Jika dibandingkan dengan hasil penelitian Mirdhayati (2004), jumlah air yang ditambahkan untuk merehidrasi 24 gram bubur garut instan MP-ASI tanpa penambahan dekstrin adalah sebesar $75 \mathrm{ml}$ atau lebih besar jika dibandingkan dengan hasil penelitian ini.

Uji waktu rehidrasi dilakukan pada saat produk MPASI berbentuk bubuk, kemudian dilakukan penambahan air dengan jumlah yang didapat pada uji seduh untuk masing-masing bubur jagung instan sehingga produk menjadi bubur dengan kekentalan yang merata. Waktu rehidrasi yang diharapkan pada produk instan adalah yang lebih singkat sehingga mempermudah proses penyajiannya. Namun ukuran dan sebaran partikel bubuk, proses pencampuran bahan dan komposisi bahan penyusun dapat memengaruhi lama penyerapan air. Waktu rehidrasi dapat ditingkatkan dengan pengadukan. Waktu rehidrasi kedua sampel bubur jagung instan lebih singkat dibandingkan waktu rehidrasi bubur MP-ASI komersial.

Kapasitas penyerapan air dinyatakan dengan banyaknya air yang diserap tiap gram bahan. Hasil penelitian menunjukkan bahwa kapasitas penyerapan air bubur jagung instan sebesar 2,63 g/g bk untukFormulasi A dan 2,65 g/g bk untuk Formulasi B. Jika dibandingkan dengan nilai kapasitas penyerapan air bubur MP-ASI komersial (4,06 g/g bk), maka nilai kapasitas penyerapan air kedua sampel bubur jagung MP-ASI ini lebih rendah.

Daya cerna pati bubur berbahan baku tepung jagung instan Formulasi A $(83,87 \%$ bk) lebih tinggi daripada daya cerna pati bubur jagung instan Formulasi B (82,39\% bk). Namun daya cerna pati kedua sampel bubur jagung instan ini lebih rendah daripada daya cerna pati bubur MP-ASI komersial $(86,14 \%)$. Hal ini kemungkinan disebabkan oleh perbedaan tingkat gelatinisasi dan kapasitas penyerapan air masing-masing sampel bubur. Njintang \& Mbofung (2006) melaporkan bahwa peningkatan daya cerna pati dapat disebabkan oleh peningkatan gelatinisasi pati dan kemampuan untuk mengikat air.

Pengujian sifat organoleptik dilakukan terhadap kedua sampel bubur jagung instan dan bubur MP-ASI komersial sebagai pembanding. Uji organoleptik yang dilakukan yaitu uji hedonik terhadap warna, aroma, kekentalan, rasa, penerimaan umum (overall), menggunakanskala penilaian dari 1 sampai 7. Semakin besar nilai yang diberikan panelis, maka semakin besar kesukaan panelis tersebut terhadap parameter hedonik yang diamati.

Hasil uji hedonik terhadap sampel bubur jagung instan dapat dilihat pada Tabel 4. Nilai rata-rata kesukaan terhadap warna dan aroma pada kedua sampel bubur jagung instan berbeda nyata dengan nilai rata-rata kesukaan terhadap warna dan aroma bubur MP-ASI komersial. Warna kedua sampel bubur jagung instan lebih disukai dibandingkan warna bubur MP-ASI komersial. Hal ini dapat disebabkan oleh perbedaan bahan-bahan penyusun dan proses pembuatan bubur tersebut. Pada proses pembuatan bubur jagung instan, pengeringan menggunakan drum dryer hanya dilakukan pada proses pembuatan tepung jagung pragelatinisasi, sedangkan bahan-bahan penyusun lain seperti susu skim, gula halus dan minyak sawit dicampurkan tanpa penambahan air dan tanpa pemasakan kembali karena bahan-bahan semuanya sudah matang (metode pencampuran kering). Metode pencampuran kering dapat meminimalkan kehilangan komponen zat gizi yang terkandung pada bahan-bahan penyusun bubur instan dan juga dapat mempertahankan warna alami dari tepung jagung. Lain halnya dalam pembuatan bubur MP-ASI komersial yaitu dengan cara memasak campuran bahan penyusunnya terlebih dahulu kemudian baru dikeringkan dengan drum dryer, sehingga memungkinkan terjadinya reaksi pencokelatan pada produk tersebut dan warnanya kurang disukai oleh sebagian besar panelis.

Aroma bubur MP-ASI komersial lebih disukai dibandingkan kedua sampel bubur jagung instan. Proses pembuatan bubur instan MP-ASI menggunakan metode pencampuran basah, dimana semua bahan dicampurkan terlebih dahulu kemudian baru dikeringkan menggunakan drum dryer. Metode pencampuran basah lebih menfasilitasi terjadinya reaksi pencokelatan yang mendorong terbentuknya flavor khas yang disukai pada bubur MP-ASI komersial.

Nilai rata-rata kesukaan terhadap kekentalan, rasa dan penerimaan umum untuk kedua sampel bubur instan tidak berbeda nyata dengan bubur komersial berdasarkan hasil analisis statistik ( $\leq 0,05)$. Nilai rata-rata kesukaan terhadap kekentalan, rasa dan penerimaan umum untuk ketiga sampel bubur instan yang diuji berturut-turut berkisar antara 4,98-5,45; 4,66-4,82; dan 5,15-5,21, nilai ini menandakan panelis secara umum agak suka terhadap kekentalan, rasa dan penerimaan umum untuk ketiga sampel bubur instan tersebut.

\section{Kesimpulan dan Saran \\ Kesimpulan}

Berdasarkan hasil penelitian dapat ditarik beberapa kesimpulan sebagai berikut:

1) Perlakuan lama pemasakan slurry jagung menyebabkanadanya pengaruhyang signifikan terhadap kekuatan gel, densitas kamba, swelling volume, solubility, kapasitas penyerapan air, wettability, kadar air, kadar protein dan kadar karbohidrat tepung tepung jagung pragelatinisasi, namun pengaruh yang tidak signifikan terhadap kadar abu dan kadar lemak tepung jagung pragelatinisasi.Kekuatan gel, densitas kamba dan wettability, kadar protein dan kadar karbohidrat tepung jagung pragelatinisasi cenderung menurun dengan meningkatnya lama pemasakan slurry jagung, sedangkan swelling volume, solubility, kapasitas penyerapan air, dan kadar air tepung jagung pragelatinisasi cenderung meningkat.

2) Perlakuan lama pemasakan 15 menit dipilih sebagai bahan baku bubur jagung instan karena memiliki 
sifat fisik yang sesuai dan komposisi kimia yang masih baik untuk digunakan dalam pembuatan bubur instan.

3) Bubur jagung instan menggunakan Formulasi B (tepung jagung $40 \mathrm{~g}$, susu skim $45 \mathrm{~g}$, gula halus $5 \mathrm{~g}$ dan minyak nabati $10 \mathrm{~g})$ merupakan formulasi terpilih karena memiliki kadar zar gizi makro yang telah sesuai dengan persyaratan SNI 01-7111.12005 , daya cerna protein sebesar $88,67 \%$ bk dan daya cerna pati sebesar $82,39 \%$ bk, dan sifat organoleptik yang lebih disukai dibandingkan bubur MP-ASI komersial

\section{Saran}

Saran yang dapat diberikan untuk penelitian lebih lanjut adalah penelitian mengenaiscale-up pembuatan bubur jagung instan MP-ASI dengan fortifikasi zat gizi mikro (vitamin dan mineral) sehingga memenuhi persyaratan MP-ASI bubuk instan menurut SNI 017111.1-2005. Pada pembuatan bubur jagung instan MPASI disarankan menggunakan Formulasi B dimana kandungan zat gizi makronya sudah memenuhi persyaratan SNI 01-7111.1-2005.

\section{Daftar Pustaka}

Aguilera, Y., Esteban, RM., Benitez, V., Molla E., \& Martin-Cabrejas, M. 2009. Starch, functional properties, and microstructural characteristics in chickpea and lentill as affected by thermal processing. Journal og Agricultural and Food Chemistry. 57(22): 10.682-10.688.

[BSN] Badan Standardisasi Nasional. 2005. SNI 017111.1-2005. Makanan Pendamping Air Susu Ibu (MP-ASI) Bagian 1: Bubuk Instan. Jakarta.

[BPS] Badan Pusat Statistik Republik Indonesia (Statistik Indonesia). 2010. Luas Panen, Produktivitas dan Produksi Jagung Menurut Propinsi. http://www.bps.go.id/aboutus.php?search=1 [21 Maret 2010].

BeMiller, JN., \& Whistler, RL. 1997. Carbohydrate in R. Fennema Owen (Ed). Food Chemistry. Ohio State: Columbus.

Catsimpoolas, N., \& Meyer, E. 1970. Gelation phenomena of soybean globulins. I. Proteinprotein interactions. Cereal Chemistry. 47: 559570

Chun SY, Yoo B. 2006. Steady and dynamic shear rheological properties of sweet potato flour dispersion. European Food Research and Tech 223: 313-319.

De la Torre-Gutiérrez L, Chel-Guerro LA, BetancurAncona D. 2008. Functional properties of square banana (Musa babisiana) starch. J Food Chem 106: 1138-1144.

Elkhalifa AO, Schiffler B, Bernhardt R. 2005. Effect of fermentation on the functional properties of sorghum flour. J Food Chem 92: 1-5.
Graybosch et al. 2003. Functional properties of waxy wheat flour: genotypic and environmental effect. $J$ Cereal Sci 38: 69-76.

Hodge JE, Osman EM. 1976. Carbohydrates. Di dalam: Fennema OR, editor. Principles of Food Science part I Food Chemistry. New York: Marcel Dekker Inc.

Hoover R, Sosulski F. 1986. Effect of cross linking on functional properties of legume. Starches/Stärke38: 149-155.

Kadan RS, Bryant RJ, Pepperman AB. 2003. Functional properties of extruded rice flours. J Food Sci 68: 1660-1672.

Khomsatin, S. 2011. Kajian pengaruh pengukusan bertekanan (steam pressure treatment) terhadap sifat fisikokimia tepung jagung [tesis]. Bogor: Sekolah Pascasarjana, Institut Pertanian Bogor.

Lindent G, Lorient D. 1995. New Ingredient in Food Processing (Biochemistry and Agriculture). New York: CRC Press.

Ma $\mathrm{Z}$ et al. 2011. Thermal processing effects on the functional properties and microstructure of lentil, chickpea, and pea flours. Articel in Press. Food Research International.

Marta, H. 2011. Sifat fungsional dan reologi tepung jagung nikstamal serta contoh aplikasinya pada pembuatan Makanan Pendamping ASI (MP-ASI)) [tesis]. Bogor: Sekolah Pascasarjana, Institut Pertanian Bogor.

Mirdhayati I. 2004. Formulasi dan karakterisasi sifat-sifat fungsional bubur garut (Maranta arundinaceae Linn) instan sebagai makanan pendamping air susu ibu (MP-ASI) [tesis]. Bogor: Sekolah Pascasarjana, Institut Pertanian Bogor.

Mondragón M, Mendoza-Martínez AM, Bello-Pérez LA, Peña JL. 2006. Viscoelastic behavior of nixtamalized maize starch gels. Carbohydrate Polym 65: 314-320.

Njintang, YN, Mbofung CMF. 2006. Effect of precooking time and drying temperature on the physicochemical characteristics and in-vitro carbohydrate digestibility of taro flour. $L W T$ 39: 684-691.

Richana N, Suarni. 2007. Teknologi pengolahan jagung. http://balitsereal. Litbang.deptan.go.id/ind//bjagung/empat.pdf [21Maret 2010).

Sefa-Dedeh S, Cornelius B, Sakyi-Dawson E, Afoakwa EO. 2004. Effect of nixtamalization on the chemical and functional properties of maize. $J$ Food Chem 86: 317-324.

Tan, Y., \& Chinnaswamy, R. 1993. Moleculer properties of cereal based breakfast foods. Starke 11: 391396.

Winarno, FG. 2004. Kimia Pangan dan Gizi. Jakarta: Gramedia Pustaka Utama. 